\title{
LPP/MLL Fusion Protein
}

National Cancer Institute

\section{Source}

National Cancer Institute. LPP/MLL Fusion Protein. NCI Thesaurus. Code C99433.

A fusion protein encoded by the LPP/MLL fusion gene. This protein is comprised of the $\mathrm{N}$-terminal half of the lipoma-preferred partner protein, including the proline-rich region and leucine zipper motifs, and the first LIM domain, fused with the C-terminal portion of the histone-lysine N-methyltransferase MLL protein. 